\title{
DETERMINANTS OF ADAPTATION TO DEFORESTATION AMONG FARMERS IN MADAGALI LOCAL GOVERNMENT AREA OF ADAMAWA STATE, NIGERIA
}

\author{
S.B. Mustapha, P.M. Bzugu, I.M. Ali, A. Abdullahi, Researchers \\ University of Maiduguri, Nigeria \\ Phone: +2347060573884, E-mail: shettimabulama@yahoo.com
}

Received August 9, 2012

\begin{abstract}
The study examined the determinants of adaptation to deforestation among farmers in Madagali Local Government Area of Adamawa state, Nigeria. Structured interview schedule were used to obtain information from 200 respondents selected through simple random sampling techniques. The data collected were analyzed using descriptive (frequencies and percentages) and inferential (chi - square test) statistics. The result indicated that majority (84\%) of the respondents were male with 21-40 years of age representing 58.50\%. The study also showed that most (45\%) of the respondents had attained post primary education with majority (80\%) having 6 and above years of farming experience. The respondents perceived fuel wood extraction as the major (42\%) cause of deforestation in the study area. The result showed that the most (30.50\%) frequently employed adaptation strategy against deforestation was reducing quantity of fire wood consumption. The study further showed that the factors which significantly influenced adaptation to deforestation among the respondents were age, farming experience and educational status with $X^{2}=9.216,8.697$ and 11.238 at $P<0.05$ respectively. While those factors which did not influence adaptation to deforestation among the respondents were gender, access to agricultural credit and access to extension services with $X^{2}=1.286,7.923$ and 5.862 at $P<0.05$ respectively. The major constraints faced by respondents in adaptation to deforestation were lack of capital and lack of accessible alternative energy. The study recommends that awareness campaign should be mounted to increase the level of knowledge of respondents on the significance of adaptation to deforestation. Respondents should also be encouraged towards establishment of adaptation cooperative societies in order to take advantage of some government policies and programmes.
\end{abstract}

\section{KEY WORDS}

Adaptation; Deforestation; Determinants; Farmers; Nigeria.

Deforestation is defined as the indiscriminate felling of trees without their replacement [4]. In other words, deforestation is the removal or damage of vegetation in a forest to the extent that it no longer supports its natural flora and fauna [7]. According to the united nation's framework convention on climate change (UNFCCC), the overwhelming direct cause of deforestation is agriculture; with subsistence farming responsible for $32 \%$, logging $14 \%$ and fire wood removal makes up 5\% [10]. Adamawa state is believed to be naturally affected by deforestation because sparsely covered by vegetation which deviates from its natural formation. The human factor also contributes immensely to deforestation in the study area. Studies showed that $84 \%$ of the populace relies solely on fire wood for cooking [10].
This observation also reveals that $57 \%$ of the total population have been using fire wood for over 10 decades, which was an indication that the activity of deforestation has been taking place for quit a long time. Such an alarming scenario of deforestation has posed a growing threat to the natural as well as socio economic environment of the farming households of Adamawa state as a whole.

In an attempt to reduce the effects of deforestation on livelihoods in Adamawa state, farming households were compelled to develop some adaptation strategies, as farming households responds to changing environmental circumstances in a variety of ways. Thus, it has been observed that the survival attitudes caused by deforestation have encouraged the development of local people 
consciousness about environment and its conservation [5]. Adaptation in this regard, is the evolutionary process whereby population becomes better suited to its habitats. In other words, adaptation is learning to cope with the impacts of climate change (deforestation) as reported by [6].

Tropical deforestation plays a central role in many of the most acute environmental threats, including global climate change, habitat degradation and unprecedented species extinction. Scientific and public concerns about these and other potentially massive ecological disruptions have incited a frowning number of studies that aims to quantify adaptation to deforestation process among farmers. Therefore, this study sought to assess adaptation to deforestation among farmers in Madagali Local Government Area of Adamawa state.

Statement of the problem. In Nigeria, the greatest problem facing human existence has been deforestation and environmental degradation. As a result of deforestation, trees have undergone substantial deterioration, particularly in the northern part of Nigeria. The vegetation of Adamawa State is a characteristic of habitat that has been altered due to human interference with its previous natural climate formulation. The cultivation, grazing activity, cutting of trees for fire wood and other purposes have a demonstratable effect on the livelihoods of the farming communities.

Some attempts have been made to study the effects of demonstration in Nigeria $[9,10]$. However there has not been any empirical study into the adaptation of deforestation among farmers implied in the study area. This study was therefore, conducted to provide empirical information on adaptation to deforestation among farmers in Madagali Local Government Area of Adamawa State. The study was carried out to address the following research questions:

i. what were the socio economic characteristic of the respondents?

ii. what were the perceived causes of deforestation among the respondents?

iii. what were the adaptation strategies employed against deforestation among the respondents?

iv. what was the relationship between socioeconomic characteristics of the respondents and their adaptation to deforestation in the study area? and

v. what were the constraints faced by respondents in adaptation to deforestation in the study area?

Objective of the study. The main objective of the study was to assess the adaptation strategies employed against deforestation by farmers in Madagali Local Government Area of Adamawa State. The specific objectives of the study were to:

i. examine the socio-economic characteristic of the respondents.

ii. identify the perceived causes of deforestation by the respondents,

iii. determine the adaptation strategies employed against deforestation by the respondents,

iv. examine the effect of socio-economic factors on adaptation to deforestation by the respondents, and

v. investigate the constraints faced by respondents in adaptation to deforestation in the study area.

\section{METHODOLOGY}

The study area. The study was carried out in Madagli Local Government Area (LGA) of Adamawa State. Madagali LGA is located between latitudes $10^{\circ}$ and $11^{\circ}$ and longitudes $12^{\circ}$ and $15^{\circ}$ of the Greenwich meridian and covers approximately an area of $903 \mathrm{~km}^{2}$ [2]. The area has an estimated population of 134,827 [8]. The vegetation is made up of grasses and some stunted trees in some parts of the area. The rainfall lasts for about 4-5months in a year with an average rainfall of 700-1000 mm per annum [2]. The dry season begins in November and terminates in early June of the following year. Farming is the principal economy of the people in the area. The climate and the rich alluvial soil of the area favours the cultivation of food crops such as sorghum, millet, maize, rice and cassava. It also favours the production of local cash crops such as cowpea, groundnuts, sesame and sugar cane on a large scale basis. Livestock production is also very important in the study area and is one of the largest concentrations of cattle in Adamawa state. Fishing is a common practice among those living around riverbank areas. 
Sources of data. Primary data was mainly used for the study. These were generated from farming households head through the use of structured and protested interview schedules. The interviews were conducted by enumerators from Borno State Agricultural Development Programme (BOSADP) who were trained for the purpose. Secondly, information from Areas Extension Officers (AEOS) of BOSADP and Area Forestry Officers (AFOS) of the ministry of environment were used to complement the primary data. Other sources of secondary information includes, textbooks, journals and other write up that were relevant to the study.

Sampling procedure and techniques of data analysis. Simple random sampling techniques were employed to select the respondents of the study. To ensure effective coverage of the study area, respondents were randomly selected from each of the districts that contituuted the study area (Duhu, Gulak, Kirchinga, Madagali and Sukur). Five villages were chosen randomly from each district because of the fair distribution of villages among the districts, making a total of 25 villages selected from the districts. Eight respondents were selected at random from each of the selected 25 villages making a total of 200 respondents as the sample size of the study. The data were analyzed using descriptive (frequency distribution and percentages) and inferential (chisquare test) statistics. The frequency distribution and percentages were used to achieve specific objectives (i), (ii), (iii) and (v). While the chisquare test was used to achieve objective (iv). The chi-square statistics was used as expressed below:

$$
\mathrm{X}^{2}=\sum\left[(0 \mathrm{i}-\mathrm{Ei})^{2}(\mathrm{Ei})^{-1}\right],
$$

where $\mathrm{X}^{2}=$ chi-square statistic; $\mathrm{Oi}=$ observe value of variable; $\mathrm{Ei}=$ expected value of variable; $\sum$ $=$ summation sign. The variable used as determinants in the study were: Gender (GD) $=1$ if male, 0 otherwise; Age $(\mathrm{AG})=1$ if $<40$ years, 0 otherwise; Marital status (MS) $=1$ if married, 0 otherwise; Farming experience (FE) $=1>$ if 6years, 0 otherwise; Educational status $(\mathrm{ES})=1$ if $>$ WAEC/SSCE/TC 0 otherwise; Household size $(\mathrm{HS})=1$ if up to $>6$ in number, 0 otherwise; Access to agricultural credit $(\mathrm{AC})=1$ if acquired credit, 0 otherwise; Access to extension services $(\mathrm{AE})=1$ if had contact with extension agents, 0 otherwise; Access to mass media $(\mathrm{am})=1$ if had access to mass media, 0 otherwise.

\section{RESULTS AND DISCUSSION}

Socio-economic characteristics of respondents. The distribution of respondents by socioeconomic characteristics is presented in Table 1. The socio-economic variables studied include gender, age, marital status, farming experience, educational status, household size and extension contact of the respondents. Table 1 shows that majority (84\%) of the respondents were male, while female constitutes only $16 \%$ in the study area. This implies that gender is a significant factor in agriculture because of its vital role in determining farming activities in the study area. This could also influence the adaptive capacity to deforestation. In addition, majority (85\%) of the respondents were married and were in their active and economically productive age (21-40 years) representing $58.50 \%$, therefore labour demanding strategies could also be employed.

On the level of education, the result shows in Table 1 that most $(45 \%)$ of the respondents had attained post primary education. This implies that the respondents could apprehend the techniques of adaptation strategies against deforestation. The result also shows that majority (80\%) of the respondents had 6 years and above farming experience. The implication could be that they employ adaptation strategies against deforestation out of their experience. Table 1 indicated that majority $(81 \%)$ of the respondents had household size of 6 in number and above, while only $19 \%$ of the respondents had less than 6 in number. This implies that adaptation strategies that demands more hands/labour could be met by the respondents. The study, also indicates that most $(44 \%)$ of the respondents had no contact with extension agents over the year. However, $38 \%$ attested that they had 1-3 contacts with extension agents per annum. The study implies that there was low level of extension services which affects the awareness and use of adaptation strategies against deforestation in the study area. 
Table 1 - Distribution of respondents by socio-economic characteristics ( $\mathrm{N}=200)$

\begin{tabular}{|c|c|c|c|}
\hline & Socio-economic variable & Frequency (No.) & Percentage (\%) \\
\hline \multicolumn{4}{|l|}{$\overline{\text { Gender }}$} \\
\hline & Male & 168 & 84.00 \\
\hline & Female & 32 & 16.00 \\
\hline \multicolumn{4}{|c|}{ Age (years) } \\
\hline & 20 and below & 42 & 21.00 \\
\hline & $21-30$ & 55 & 27.50 \\
\hline & $31-40$ & 62 & 31.00 \\
\hline & 41 and above & 41 & 20.50 \\
\hline \multicolumn{4}{|c|}{ Marital Status } \\
\hline & Married & 171 & 85.50 \\
\hline & Single & 29 & 14.50 \\
\hline \multicolumn{4}{|c|}{ Farming experience(years) } \\
\hline & Less than 6 & 40 & 20.00 \\
\hline & $6-10$ & 57 & 28.00 \\
\hline & $11-15$ & 63 & 31.50 \\
\hline & 16 and above & 40 & 20.00 \\
\hline \multicolumn{4}{|c|}{ Educational status } \\
\hline & Illiterate & 19 & 09.50 \\
\hline & Quranic education & 23 & 11.50 \\
\hline & Primary education & 68 & 34.00 \\
\hline & WAEC/SSCE/TC & 70 & 35.00 \\
\hline & Tertiary education & 20 & 10.00 \\
\hline \multicolumn{4}{|c|}{ Household size (number) } \\
\hline & Less than 6 & 38 & 19.00 \\
\hline & $6-10$ & 72 & 36.00 \\
\hline & $11-15$ & 65 & 32.50 \\
\hline & 16 and above & 25 & 12.00 \\
\hline \multicolumn{4}{|c|}{ Extension contact (per year) } \\
\hline & No contact & 88 & 44.00 \\
\hline & $1-3$ & 76 & 38.00 \\
\hline & $4-6$ & 30 & 15.00 \\
\hline & 7 and above & 06 & 03.00 \\
\hline
\end{tabular}

Source: Field survey, 2010.

Perceived causes of deforestation by respondents. Table 2 shows the perception of respondents on the causes of deforestation in the area. The study reveals that most (42\%) of the respondents perceived fuel wood extraction as the major cause of deforestation. This was closely followed by farming activities $(27.50 \%)$ and bush burning (12.50\%). While, the least perceived cause of deforestation was road/building construction with only $4 \%$ of the respondents attesting to it. The study shows that the root cause of deforestation was among the rural communities as perceived by the respondents. The implication could be that adaptation strategies against deforestation that could be targeted towards farming communities might effectively yield the desired result with the support of extension services. This was because, the deforestation was perceived to cause by human activities rather than natural as only $6 \%$ of the respondents claimed that deforestation is caused by drought.

Table 2 - Respondents perception on causes of deforestation $(\mathrm{N}=200)$

\begin{tabular}{lll}
\hline Causes & Frequency (No.) & Percentage (\%) \\
\hline Farming activities & 55 & 27.50 \\
Fuelwood extraction & 85 & 42.50 \\
Bush burning & 25 & 12.50 \\
Road/building construction & 8 & 04.00 \\
Overgrazing & 15 & 07.50 \\
Drought & 12 & 06.00 \\
\hline
\end{tabular}

Source: Field survey, 2010. 
Adaptation Strategies employed by respondents. Table 3 indicated the adaptation strategies employed against deforestation by respondents. The result shows that the most $(30.50 \%)$ frequently employed adaptation strategy against deforestation was reducing quantity of firewood consumption among the respondents. This was followed by the practice of zero tillage (23\%) in the study area. While, the least employed adapta- tion strategy was the use of fuel efficient wood stoves $(3.50 \%)$, which was closely followed by the use of alternative energy (kerosene), represented by $5 \%$ of the respondents. The study implies that the respondents might be ready to use alternative sources of energy if given the opportunity (availability and affordability), this could be attributed to the impact of deforestation in the study area.

Table 3 - Distribution of respondents by adaptation strategies employed against deforestation $(\mathrm{N}=200)$

\begin{tabular}{lll}
\hline Causes & Frequency (No.) & Percentage (\%) \\
\hline Use of fuel efficient wood stoves & 07 & 03.50 \\
Protection of economic trees & 27 & 13.50 \\
Reducing quantity of firewood consumption & 61 & 30.50 \\
Practice of zero tillage & 46 & 23.00 \\
Use of alternative energy (kerosene) & 10 & 05.00 \\
Participation in farm forestry & 21 & 10.00 \\
Use of cow dung for cooking & 16 & 08.00 \\
Use of corn straw for cooking & 12 & 06.00 \\
\hline
\end{tabular}

Source: Field survey, 2010

Determinants of adaptation to deforestation among respondents. The chi-square results of the determinants of adaptation to deforestation among respondents were presented in Table 4. The variables studied include gender, age, marital status, farming experience, educational status, household size, access to agricultural credit and access to extension services. The result showed the significant variables which include age, farming experience and educational status; $\mathrm{X}^{2}=9.216$, 8.697 and 11.238 at $\mathrm{P}<0.05$ respectively. The age of the farmer affected the farmer's knowledge and the awareness of the activities in the surrounding environment among other farmers. This indicates that the age influences the farmers capacity to adapt deforestation. The finding supports that of Krishna [7], that age significantly influence the adaptive capacity of farmers against deforestation. Farming experience affected the farmer's knowledge and awareness of deforestation and its impact in the farming communities. This shows that farming experience influences the farmer's adaptive capacity to deforestation. Also, an educated farmer could readily access information on deforestation and how it could be adapted. Formal education could therefore be a critical factor influencing the effectiveness of farmer's adaptive capacity to deforestation; as reported by Oladusu et al [9].

Table 4 - Chi-square results of the determinants of adaptation to deforestation in the study area

\begin{tabular}{lllll}
\hline Causes & Degree of freedom & Calculated x2 & P-value & Remark \\
\hline Gender & 1 & 1.286 & 3.841 & SN \\
Age & 3 & 9.216 & 7.815 & SS \\
Farming experience & 3 & 8.697 & 7.815 & SS \\
Educational status & 4 & 11.238 & 9.488 & SS \\
Access to agricultural credit & 4 & 7.923 & 9.488 & SN \\
Access to extension service & 3 & 5.862 & 7.815 & SN \\
\hline
\end{tabular}

Source: Field survey, 2010

x2 = calculated chi-square

$\mathrm{SS}=$ Statistically significant at at $\overline{\mathrm{P}} \leq 0.05$

$\mathrm{P}$-value $=$ Tabulated $\mathrm{x} 2$ (critical value)

$\mathrm{SN}=$ Statistically insignificant at $\overline{\mathrm{P}} \leq 0.05$

Table 4 shows that gender, access to agricultural credit and access to extension services; $\mathrm{X}^{2}=1.286,7.923$ and 5.862 at $\mathrm{P}<0.05$ respectively were statistically insignificant variables. Gender was thus not a significant factor to influ- ence adaptation against deforestation among the respondents. Also agricultural credit and extension services did not influence adaptation to deforestation by respondents. This could be due to inaccessibility of respondents to extension and 
credit services. The implication could be that the respondent's level of adaptation to deforestation could be affected negatively.
Constraints of adaptation to deforestation by respondents. The constraints of adaptation to deforestation was presented in Table 5.

Table 5 - Distribution of respondents by constraints adaptation to deforestation $(\mathrm{N}=200)$

\begin{tabular}{lll}
\hline Causes & Frequency (No.) & Percentage (\%) \\
\hline Lack of awareness & 37 & 18.50 \\
Lack of sufficient labour & 25 & 12.50 \\
Lack of accessible alternative energy & 48 & 24.00 \\
Lack of capital & 50 & 25.00 \\
Poor extension services & 40 & 20.00 \\
\hline
\end{tabular}

Source: Field survey, 2010.

The result reveals that lack of capital was asserted by most $(25 \%)$ of the respondents as constraint to adaptation against deforestation. This could not be unexpected, due to the fact that most of the farming households in the study area are peasant farmers with low income earnings. The second most important constraint was lack of accessible alternative energy, as asserted by $24 \%$ of the respondents. This could be due to partly to , as a result of the high prices associated with most of the alternative sources of energy e.g ke- rosene, and therefore respondents could not afford to use. This implies that the respondents level of adaptation against deforestation could be affected negatively which does not augur well for the environment and the society as well. Other constraints faced by the respondents in adaptation to deforestation were poor extension services, lack of awareness and lack of sufficient labour with $20 \%, 18.50 \%$ and $12.50 \%$ of the respondents claiming respectively.

\section{REFERENCES}

Ajayi, O.C (2007). User acceptability of sustainable soil facility technologies. Lessons from farmers knowledge, attitudes and practices in southern Africa. Journal of Sustainable Agriculture, vol. 30 (3): 21-40

ASMLS (1999). Adamawa State Ministry of Land and Survey (ASMLS), Annual report, Adamawa State, Nigeria.

Ayuba, H.K. (2008). Towards combating desertification and deforestation in Yobe state, Nigeria. Yobe Journal of Environment and Development, vol. 1, No. 1pp 1-5.

FAO (2005). State of the World's Forests. Food and Agricultures Organization (FAO) of the United Nations, Rome, Italy.

FAO (2007). Deforestation: Tropical Forests in Decline. Food and Agriculture Organization (FAO) of the United Nations, Rome, Italy.

Gwary, D.M. (2010). Climate Change Adaptation and Migration Options for Improving Food Security in Nigeria. Lead paper presenting at the 6th National Cconference in Organic Agriculture held at the University of Maiduguri, Nigeria 22nd - 24th November.
Krishna, K. (2004). Effects of deforestation on tree diversity and livelihoods of local community: A case study from Nepal. M.sc. Dissertation, Department of plant Ecology, Lund university, Sweden.

NPC (2006). National Population Commission (NPC); Provisional census figure; Abuja, Nigeria.

Oladosu, I.O., Ogunwale, A.B. and Ayanwuyi, E. (2002). Farmers perception of effects of deforestation on agricultural production and economic activities in selected rural communities in Orire Local Government Area of Oyo State, Nigeria. International Journal of Business and Common Market Studies vol. 1 (1): 209-216.

Oseoneoba, G.J. (1992). Fuelwood exploitation from natural ecosystem in Nigeria: Socioeconomic and Sociological implication. Journal of Rural Development, vol. 1 (1): 141-155. 